\title{
The Association of K88 Antigen with Haemagglutinating Activity in Porcine Strains of Escherichia coli
}

\author{
By G. W. JONES AND J. M. RUTTER \\ Agricultural Research Council, Institute for Research on Animal Diseases, \\ Compton, Newbury, Berkshire
}

(Received 28 February 1974; revised I May 1974)

\begin{abstract}
SUMMARY
All of 108 strains of Escherichia coli that synthesized K88 antigen caused mannose-resistant and eluting (m.r.e.) haemagglutination of guinea-pig erythrocytes in a microhaemagglutination test; none of 23 representative strains did so in a tile haemagglutination test which requires firmer binding. It was concluded that the K88 antigen was the m.r.e. haemagglutinin since (i) only K88-positive strains caused m.r.e. haemagglutination (ii) K88-positive strains grown at $18{ }^{\circ} \mathrm{C}$ failed to produce both haemagglutinin and $\mathrm{K} 88$ antigen (iii) haemagglutinating activity was not detected in K88-negative mutants of a K88-positive enteropathogenic strain, and (iv) extracts of $\mathrm{K} 88$ antigen possessed haemagglutinating activity which could not be separated from the K88 antigen by the fractionation and serological procedures examined. Haemagglutination appears to resemble the attachment of K88-positive bacteria to the gut wall in enteric disease and the haemagglutination test may assist in characterizing this mechanism.
\end{abstract}

\section{INTRODUCTION}

Serotypes of Escherichia coli that cause neonatal diarrhoea in piglets produce one of two closely related forms of K88 antigen (Sojka, I97I) designated K88ab and K88ac (Ørskov, Ørskov, Sojka \& Wittig, 1964). K88 is a proteinaceous surface component of the bacterial cell (Stirm, Ørskov, Ørskov \& Birch-Andersen, 1967a; Stirm, Ørskov, Ørskov \& Mansa, I $967 b$ ) and is the product of an episomal gene (Ørskov \& Ørskov, I966; Smith \& Linggood, 1970) which is not expressed at $18{ }^{\circ} \mathrm{C}$ (Ørskov, Ørskov, Sojka \& Leach, I96I).

Arbuckle (1970) observed that serotypes of E. coli that usually produce K88 antigen attach to the intestinal mucosa of piglets, and Smith \& Linggood (197I) concluded that the virulence of $E$. coli for early-weaned piglets increased after the bacteria had acquired the ability to produce K88 antigen. Jones \& Rutter (I972) demonstrated that K88 antigen was synthesized by a K88-positive enteropathogenic strain of $E$. coli in the small intestine of both gnotobiotic and conventional neonatal piglets where it functioned as an adhesin enabling the bacteria to adhere to and colonize the mucosa; the greatly reduced virulence of a K88-negative mutant strain was attributed to its inability to colonize the mucosa of the small intestine.

In addition to the adhesive activity of the K88 antigen demonstrated in vivo, Stirm et al. ( $1967 a$ ) showed that in two laboratory-prepared cultures of E. coli, the K88 antigen was associated with mannose-resistant haemagglutinating activity. Although haemagglutinating activity may reflect a property that contributes to the infectivity of pathogenic E. coli, this has not been clearly demonstrated. For example, there is no apparent correlation between haemagglutinating activity and pathogenicity in strains of $E$. coli isolated from human 
infants (Duguid, I968) or pigs (Punyashthiti \& Finkelstein, I97I); in contrast, the haemagglutinating activity of strains of $E$. coli that cause diarrhoea in adult humans (Punyashthiti \& Finkelstein, I97I), and in cultures of E. coli that are virulent for chicken embryos (Powell \& Finkelstein, I966), suggest that such a relationship may exist in some strains of $E$. coli. Since the adhesive nature of the K88 antigen is important in the pathogenesis of neonatal diarrhoea in piglets, the value of a haemagglutination test which demonstrates this mechanism is evident.

\section{METHODS}

Strains of E. coli. Ten strains representing serotypes of porcine enteropathogenic E. coli, including strains wi [OI49:K9I (B), K88ac (L):Hio], w3 [OI4I :K85ab (B), K88ab (L): H4], w5 [O8:K87 (B), K88ab (L):Hi9], w9 [Or47:K89 (B), K88ac (L):Hi9] and wio [O8:K87 (B), K88ac (L): Hi 9] were supplied by Mr W. J. Sojka, Central Veterinary Laboratory, Weybridge, Surrey. Twenty-two strains belonging; to the same OK groups including strain PIIo [Or 47:K89 (B), K88ac (L)] were given by Dr H. W. Smith, Houghton Poultry Research Station, Huntingdon. K88-negative mutant strains were derived (q.v.) from strain WI; strain WI(J2) was isolated after ethidium bromide treatment, strain WI(J35) was isolated after u.v. irradiation and strain WI(J134) was a spontaneous mutant. Strains D282

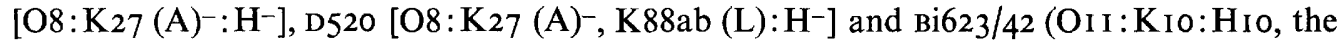
test strain for the Hro antigen) were supplied by Dr Ida Ørskov, Statens Seruminstitut, Copenhagen, Denmark. Cultures of $E$. coli incriminated in enteric disease of pigs were kindly given by Mrs A. F. Gush and Mr A. J. E. Woods, Veterinary Investigation Centre, Reading, and their identity confirmed by the methods of Edwards \& Ewing (I962), Sojka (1965) and Cowan \& Steel (1965). All cultures were examined for K88 antigen with specific $\mathrm{K} 88 \mathrm{~b}$ and $\mathrm{K} 88 \mathrm{c}$ antisera (q.v.). The four strains used as controls in the tile haemagglutination test 9044 (m.r.e. haemagglutinin), 9084 (mannose-sensitive haemagglutinin), 9085 (mannose sensitive and m.r.e. haemagglutinin) and 9090 (no haemagglutinating activity) were obtained from Professor J. P.Duguid, Bacteriology Department, University of Dundee, Scotland.

Isolation of K88-negative mutants of strain wI by ethidium bromide treatment. Strain WI was grown for 20 to 60 generations in Oxoid nutrient broth No. 2, containing ethidium bromide (3,8-diamino-5-ethyl-6-phenyl-phenanthridium bromide) (BDH Chemicals Ltd, Poole, Dorset) at concentrations of 25 to $100 \mu \mathrm{g} / \mathrm{ml}$. Cultures were plated onto Tergitol-7 medium (Scherer, I966) and after incubation at $37^{\circ} \mathrm{C}$ for $48 \mathrm{~h}$ the colonies were examined for $\mathrm{K} 88$ antigen with $\mathrm{OK}$ antisera raised against strain w9.

Isolation of K88-negative mutants of strain wi by u.v. irradiation. Nutrient broth cultures of strain WI were diluted to approximately $I \times 10^{7}$ colony forming units (c.f.u.) $/ \mathrm{ml}$ and irradiated (Universal UV Lamp, Gelman, Ann Arbor, Michigan, U.S.A.) at a distance of $10 \mathrm{~cm}$ to give approximately $0.1 \%$ survival; the survivors were cultured in nutrient broth at $37^{\circ} \mathrm{C}$ for $24 \mathrm{~h}$ before plating onto Tergitol-7 medium. Colonies were examined for K88 antigen.

Selection of spontaneous K88-negative mutants. Rabbit OK antiserum prepared against strain w9 was heated at $56{ }^{\circ} \mathrm{C}$ for $30 \mathrm{~min}$, sterilized by filtration (220 $\mathrm{nm}$, Millipore) and added to semi-solid agar in a Craigie tube (Cruickshank, 1965). A nutrient broth culture of strain WI was inoculated into the centre tube and after $18 \mathrm{~h}$ incubation at $37^{\circ} \mathrm{C}$, bacteria from the outer tube were streaked onto blood agar plates and incubated at $37^{\circ} \mathrm{C}$ overnight. Colonies were examined for K88 antigen.

Antisera and serological tests. OK, $\mathrm{O}$ and $\mathrm{H}$ antisera (Sojka, 1965) and $\mathrm{K} 88$ antisera 
(Stirm et al. $1967 b$ ) were prepared in rabbits and examined as described previously (Jones \& Rutter, 1972). Specific K88b antiserum was prepared by absorbing w5 OK antiserum with live WIo bacteria, and specific K88c antiserum by absorbing w $10 \mathrm{OK}$ antiserum with live w5 bacteria.

$\mathrm{O}, \mathrm{H}$ and $\mathrm{K}$ agglutination tests and immunodiffusion (Ouchterlony) tests were as described by Jones \& Rutter (1972). Immunoelectrophoresis was carried out in a medium of $\mathrm{I} \%(\mathrm{w} / \mathrm{v})$

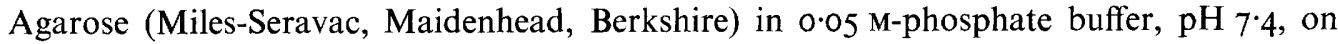
glass slides $(5 \times 7.5 \mathrm{~cm})$ at $10 \mathrm{~mA} /$ slide.

Tile haemagglutination tests (Duguid \& Gillies, 1957). One drop $(0.05 \mathrm{ml})$ of red cell suspension was mixed with one drop of saline $(0.85 \% \mathrm{NaCl})$ and one drop of bacterial suspension in the depression of a porcelain tile. The tile was agitated (Orbital shaker, Luckham Ltd, Burgess Hill, Sussex) either at $4{ }^{\circ} \mathrm{C}$ for $20 \mathrm{~min}$ or at room temperature for $20 \mathrm{~min}$, after which it was chilled and the test continued at $4{ }^{\circ} \mathrm{C}$. The tile was shaken at $37{ }^{\circ} \mathrm{C}$ or warmed over a bunsen flame to test for elution. Whole blood from guinea pigs, cows, sheep and fowl was freshly collected with sodium citrate $(3.8 \%$, w/v, in distilled water) as anticoagulant; defibrinated horse blood (Wellcome Reagents Ltd, Beckenham) and washed packed human $O$ red cells (kindly supplied by the Blood Transfusion Centre, Oxford) were also used. The red cells were washed three times in saline and the packed cells resuspended in saline to give $3 \%(\mathrm{v} / \mathrm{v})$ suspensions. Mannose-resistant haemagglutination was detected by the addition of $0.5 \%$ D-mannose $(\mathrm{BDH})$ to the saline diluent.

Mannose-resistant and eluting haemagglutination was determined with bacteria grown on buffered glucose nutrient agar (Jones \& Rutter, 1972) at $37{ }^{\circ} \mathrm{C}$ for $18 \mathrm{~h}$; bacterial growth was suspended in saline to give about $5 \times 10^{10}$ c.f.u. $/ \mathrm{ml}$. For mannose-sensitive (m.s.) haemagglutination tests, bacteria were grown in buffered glucose nutrient broth at $37^{\circ} \mathrm{C}$ for at least $24 \mathrm{~h}$; strains were subcultured for $48 \mathrm{~h}$ on ten successive occasions before being designated negative.

Microhaemagglutination test. Doubling dilutions of bacterial suspensions from buffered glucose nutrient agar were prepared in saline with and without the addition of $0.5 \%$ D-mannose in 'Microtiter' trays (Flow Laboratories, Irvine, Ayrshire). Equal volumes $(0.025 \mathrm{ml})$ of red cell suspensions were added and the tests incubated on an ice bath (o to $3{ }^{\circ} \mathrm{C}$ ) for $\mathrm{I} h$. The trays and all reagents were chilled before use. The highest dilution of test material to give a complete and even sheet of agglutinated red cells was designated one haemagglutinating unit. Haemagglutination by cell-free K88 antigen was examined in the same way except that $0.05 \mathrm{M}$-phosphate buffered saline, $\mathrm{pH} 7.4$ (phosphate saline) was used as the diluent (Jones, 1972). Fresh citrated guinea-pig red cells were used unless otherwise stated; the cells were washed twice in saline, resuspended to the original blood volume and diluted in ice cold saline to give a $3 \%(\mathrm{v} / \mathrm{v})$ suspension containing about $\mathrm{I} \times 10^{8}$ red cells $/ \mathrm{ml}$. Bacterial suspensions were prepared as described for the tile haemagglutination test.

Microhaemagglutination inhibition (h.i.) test. To doubling dilutions of antiserum previously heated at $56^{\circ} \mathrm{C}$ for $30 \mathrm{~min}$, an equal volume of four to eight h.a. units was added; the mixtures were incubated at $37^{\circ} \mathrm{C}$ for $2 \mathrm{~h}$, chilled, and one volume of cold guinea-pig red cell suspension added. Tests were read after incubation on an ice bath for $\mathrm{I} h$.

Extraction and examination of the K88 antigen of strain WI. Extraction of K88 antigen (Jones \& Rutter, I972) was based on the procedure of Stirm et al. (1967b). Preparations of $\mathrm{K} 88$ antigen were dissolved in phosphate saline and stored at $-20{ }^{\circ} \mathrm{C}$.

Protein assay. Protein concentrations were determined by the method of Lowry, Rosebrough, Farr \& Randall (195I).

Assay of $\mathrm{K} 88$ antigen. $\mathrm{K} 88$ antigen was assayed by radial diffusion (Mancini, Carbonara \& 
Heremans, 1965) in immunodiffusion agar containing $\mathrm{K} 88$ antisera prepared against strain PI I0. After incubation at $37^{\circ} \mathrm{C}$ for six days the precipitation zones were measured and the K88 content calculated by reference to an arbitrary standard (Jones, I972).

Polyacrylamide gel electrophoresis. Gels of $10 \%(\mathrm{w} / \mathrm{v})$ acrylamide and $0.27 \% N, N^{\prime}$ methylene bis-acrylamide (Kodak) were prepared in a running buffer of $0 . \mathrm{I}$ M-sodium phosphate buffer, $\mathrm{pH} 7 \cdot 2$, containing $0 \cdot 1 \%$ sodium dodecyl sulphate (SDS, specially pure; $\mathrm{BDH})$. Extracts diluted in buffer containing I $\%$ SDS were heated in a boiling water bath for one minute, applied to the gels and electrophoresed at $10 \mathrm{~mA} /$ tube for 2 to $3 \mathrm{~h}$. Gels were stained in $0.25 \%$ Brilliant Blue R (Sigma) in $7 \%(\mathrm{v} / \mathrm{v})$ acetic acid; duplicate gels were examined for antigens by the method of Virella \& Parkhouse (197I).

Exclusion chromatography. Columns ( $\times 9 \mathrm{~cm}$ ) of Sephadex G200 (Pharmacia) in $0.05 \mathrm{M}-$ phosphate buffer, $\mathrm{pH} 7.4$, and elution rates of 10 to $30 \mathrm{ml} / \mathrm{h}$ were used.

$D E A E$-cellulose chromatography. Columns $(\mathrm{I} \times 9 \mathrm{~cm})$ of DEAE-cellulose (Whatman Chromedia DE I I, Reeve Angel Scientific Ltd, London) equilibrated in 0.05 M-phosphate buffer, $\mathrm{pH} 7.4$, at $4{ }^{\circ} \mathrm{C}$ were loaded with 0.5 to $\mathrm{I} \mathrm{mg}$ protein and eluted at $10 \mathrm{ml} / \mathrm{h}$ with increasing molar concentrations of $\mathrm{NaCl}$ in buffer.

Caesium chloride isopycnic centrifugation. Caesium chloride (ultracentrifuge grade, BDH) was dissolved in phosphate saline containing K88 antigen extract. The density was calculated (Brakke, 1967 ) and adjusted to about $\mathrm{I} \cdot 3 \mathrm{~g} / \mathrm{ml}$; after centrifuging at $\mathrm{I} 50000 \mathrm{~g}$ overnight at $4{ }^{\circ} \mathrm{C}$, fractions were collected and assayed.

\section{RESULTS}

\section{Comparison of haemagglutination techniques}

Tile haemagglutination test. In preliminary tests with three K88-positive strains (WI, w9 and D520) and two K88-negative strains [WI(J2) and D282], only cultures of W9 and D282 caused haemagglutination. The haemagglutinins were mannose-sensitive, active on guineapig, horse and fowl red cells, and were present in cultures grown on nutrient agar and in nutrient broth. The same haemagglutinating activities were found in these five strains when the effects of different bacterial concentrations $\left(\mathrm{I} \times 10^{8}\right.$ to $\left.5 \times 10^{10} \mathrm{c.f} . \mathrm{u} . / \mathrm{ml}\right)$, agitation procedures and temperatures $\left(4\right.$ to $\left.37^{\circ} \mathrm{C}\right)$ were examined; m.r.e. haemagglutinins were not detected.

Examination of the tile haemagglutinating activity of $20 \mathrm{~K} 88$-positive and $20 \mathrm{~K} 88$ negative cultures of $E$. coli freshly isolated from pigs confirmed these observations. No m.r.e. haemagglutinins were detected in the K88-positive cultures although four K88negative cultures caused m.r.e. haemagglutination of guinea-pig, cow or human $\mathrm{O}$ red cells. Mannose-sensitive haemagglutination was detected in $12 \mathrm{~K} 88$-negative cultures, and in eight K88-positive cultures. The control strains (9044, 9084, 9085 and 909o) gave reproducible reactions of the m.s. and m.r.e. types and we concluded that the haemagglutinating activity associated with the K88 antigen (Stirm et al. 1967a) was not demonstrable with the tile test.

Microhaemagglutination test. In preliminary experiments, bacterial suspensions of WI, w9 and D520 caused haemagglutination of red cells from some species which was not inhibited by D-mannose $\left(0.02\right.$ to $5.0 \%$, w/v); elution occurred at $37^{\circ} \mathrm{C}$ and could be reversed at least five times without loss of titre by remixing and chilling on an ice bath. With the K88-negative bacteria WI(J2) and D282, the red cells of all the animal species sedimented to form discrete buttons on the bottoms of the cups, as they also did in the absence of bacteria.

Red cells from all the guinea pigs examined were consistently agglutinated by the three 
K88-positive cultures; between I and 10 bacteria/red cell caused complete haemagglutination at o to $3{ }^{\circ} \mathrm{C}$, but titres were at least 64 -fold lower at room temperature. Red cells from some cows, goats, sheep, chickens and humans were agglutinated by the K88-positive cultures but haemagglutination by all three K88-positive cultures occurred only with red cells from two of six chickens; between 10 and I 50 bacteria/red cell were necessary for complete haemagglutination. Horse red cells were not agglutinated by the three K88positive cultures.

Buffered glucose nutrient broth cultures of strains WI, w9 and D520 contained K88 antigen but haemagglutination was demonstrable only when the initial concentration of the bacterial suspension exceeded $\mathrm{I} \times \mathrm{IO}^{10} \mathrm{c}$.f.u. $/ \mathrm{ml}$. The haemagglutinating activity of nutrient broth cultures was then equivalent to that of nutrient agar cultures but haemagglutination was preceded by a prozone devoid of activity. Haemagglutination by nutrient agar cultures was inhibited when dilutions were prepared in nutrient broth instead of saline.

\section{Association between $\mathrm{K} 88$ antigen and the m.r.e. haemagglutinating activity}

Haemagglutinating activity of porcine strains. All of 105 strains of K88-positive E. coli (including 82 belonging to recognized enteropathogenic serotypes) produced m.r.e. haemagglutination of guinea-pig red cells in the microhaemagglutination test; between I and ro bacteria/red cell caused complete haemagglutination. No m.r.e. haemagglutinins were detected in 88 strains of K88-negative $E$. coli examined. Included in this group were 34 strains belonging to recognized enteropathogenic serotypes and three untypable strains which caused m.r.e. haemagglutination of guinea-pig red cells in the tile test.

Haemagglutinating properties of K88-positive strains grown at 37 and $\cdot{ }^{\circ} \mathrm{C}$. Thirty-four strains of K88-positive $E$. coli grown at $18{ }^{\circ} \mathrm{C}$ for $48 \mathrm{~h}$ on buffered glucose nutrient agar produced neither $\mathrm{K} 88$ antigen nor haemagglutinin. Cultures of the same strains grown at $37^{\circ} \mathrm{C}$ for $\mathrm{I} 6 \mathrm{~h}$ on the same medium produced both $\mathrm{K} 88$ antigen and haemagglutinin.

Haemagglutinating activity of the K88-positive strain w I and its K88-negative mutants. All colonies examined from broth cultures containing 0,25 or $50 \mu \mathrm{g}$ ethidium bromide $/ \mathrm{ml}$ were K88-positive; in contrast, 262 of 806 colonies examined from broth cultures containing 75 or $100 \mu \mathrm{g} / \mathrm{ml}$ did not produce K88 antigen. No m.r.e. haemagglutinating activity was detected in the K88-negative isolates whereas all the K88-positive isolates caused haemagglutination.

Only three of 648 isolates examined after u.v. irradiation were K88-negative. The three K88-negative isolates did not cause haemagglutination whereas all K88-positive isolates retained this property.

All 300 colonies isolated from Craigie tube cultures containing anti-K88 serum were both K88-negative and haemagglutinin-negative.

Properties of cell-free $K 88$ antigen extracts. Immunodiffusion and immunoelectrophoretic tests on crude extracts of K88 antigen from strain WI demonstrated traces of $\mathrm{O}$ and $\mathrm{H}$ antigens which could be removed by repeated precipitation to give antigenically pure $\mathrm{K} 88$. Two components were detected when crude K88 antigen was examined on polyacrylamide gels; the major, fast moving component was identified as K88 antigen and the minor component as $\mathrm{H}$ antigen. Only the faster component was present in antigenically pure preparations of $\mathrm{K} 88$.

Extracts of crude and antigenically pure K88 from strain WI agglutinated guinea-pig red cells at 0 to $3{ }^{\circ} \mathrm{C}$ in the presence of D-mannose $(0.5 \%, \mathrm{w} / \mathrm{v}) ; 0.2$ to $\mathrm{I} \cdot 5 \mu \mathrm{g}$ of protein agglutinated $\mathrm{I} \times 10^{8}$ red cells; no haemagglutination occurred at room temperature. $\mathrm{K} 88$ 
Table I. The inhibition of bacterial and cell-free haemagglutinins of strain $\mathrm{W}$ by selected antisera

Dilutions of antisera were incubated with 8 haemagglutinating units of cell-free K88 antigen or bacterial suspension at $37^{\circ} \mathrm{C}$ for $2 \mathrm{~h}$ after which the reaction mixture was chilled and red cells were added. Haemagglutination inhibition (h.i.) titres were the highest dilutions of serum to inhibit haemagglutination after $\mathrm{I} \mathrm{h}$ on an ice bath. Saline was added in place of red cells to tests with bacterial suspensions and the highest dilution of serum causing bacterial agglutination was recorded after overnight incubation at $4{ }^{\circ} \mathrm{C}$. Titres are the reciprocal dilutions of antisera. Precipitins (+, present; - , absent) were detected with the immunodiffusion technique. Details of the antisera and the antigenic structures of the E. coli strains are given in Methods.

\begin{tabular}{|c|c|c|c|c|c|c|}
\hline \multirow[b]{3}{*}{ Antiserum } & \multicolumn{4}{|c|}{ Cell-free K88 } & \multirow{2}{*}{\multicolumn{2}{|c|}{ Bacterial suspension }} \\
\hline & \multirow[b]{2}{*}{ H.i. titre } & \multicolumn{3}{|c|}{ Precipitins } & & \\
\hline & & $\mathrm{K} 88$ & $\mathrm{H}$ & $\mathrm{O}$ & H.i. titre & $\begin{array}{l}\text { Agglutinin } \\
\text { titre }\end{array}$ \\
\hline PI Io anti-K88 & $5 \mathrm{I} 2$ & + & - & - & 32 & 64 \\
\hline wI anti-OK & 128 & + & + & + & I6 & 512 \\
\hline WI(J2) anti-OK & $<2$ & - & + & + & $<2$ & 256 \\
\hline wi anti-O & $<2$ & - & - & + & $<2$ & 4 \\
\hline Bi623/42 anti-H & $<2$ & - & + & - & $<2$ & 256 \\
\hline Normal serum & $<2$ & - & - & - & $<2$ & $<2$ \\
\hline
\end{tabular}

extracts from five other K88-positive cultures also caused m.r.e. haemagglutination of guinea-pig red cells at 0 to $3{ }^{\circ} \mathrm{C}$.

Crude extracts from the K88-negative mutants WI(J2), WI(J35) and WI(JI34) prepared in a similar manner, contained only $\mathrm{O}$ and $\mathrm{H}$ antigens; only the $\mathrm{H}$ antigen was detected in polyacrylamide gels. Extracts of these strains did not agglutinate guinea-pig red cells in the microhaemagglutination test.

Fractionation of the cell-free haemagglutinin and K88 antigen. When extracts of strain w I were fractionated on Sephadex G200 columns the K88 antigen and haemagglutinin eluted together in the void volume as a single peak. $\mathrm{O}$ and $\mathrm{H}$ antigens, when present in the extracts, were eluted with $\mathrm{K} 88$ antigen.

The antigen and haemagglutinin were eluted from DEAE-cellulose columns as a single peak by $0 . \mathrm{I} \mathrm{M}-\mathrm{NaCl}$ in buffer (peak A). The maximum amounts of haemagglutinin, $\mathrm{K} 88$ antigen and material absorbing at $280 \mathrm{~nm}$ were recovered in the same fraction; $\mathrm{O}$ antigen, when present, was also eluted by $0 . \mathrm{I} \mathrm{M}-\mathrm{NaCl}$ in buffer. $\mathrm{H}$ antigen was eluted by $0.05 \mathrm{M}-$ phosphate buffer and nucleic acid-rich material was eluted by $\mathrm{I} \cdot \mathrm{O} \mathrm{M}-\mathrm{NaCl}$ in buffer. In some preparations, an additional peak of $\mathrm{K} 88$ antigen and haemagglutinating activity was eluted by $0.2 \mathrm{M}-\mathrm{NaCl}$ in buffer (peak $\mathrm{B}$ ); the maximum recovery of $\mathrm{K} 88$ antigen and haemagglutinin coincided in the fraction preceding the fraction with the maximum $280 \mathrm{~nm}$ absorbance. Although the ratio of maximum haemagglutinin to K88 antigen was higher in peak B compared with peak A, this ratio was more variable within peak B. In experiments conducted at room temperature $\left(22\right.$ to $25^{\circ} \mathrm{C}$ ), all detectable $\mathrm{K} 88$ antigen and haemagglutinin was eluted by $0.2 \mathrm{M}-\mathrm{NaCl}$ in buffer.

K88 antigen and haemagglutinin banded together in caesium chloride gradients at a density of approximately $\mathrm{I} \cdot 3 \mathrm{I} \mathrm{g} / \mathrm{ml}$; the maximum activities of both components coincided with the maximum absorbance at $280 \mathrm{~nm}$.

Serological analysis of the m.r.e. haemagglutinin. The results of haemagglutination inhibition tests with selected antisera prepared against $E$. coli antigens are shown in Table I. Haemagglutination by cell-free extracts of strain WI was inhibited only by PIIO K88 and WI OK antisera and these were the only antisera that contained K88 precipitins. Bacterial 
haemagglutination was also inhibited by these antisera. The h.i. titre was not related to the bacterial agglutinin titre; however, subsequent serological examinations showed that only PI IO K88 and WI OK antisera contained K88 agglutinins. In additional tests with 42 antisera prepared against live and boiled bacteria and K88 extracts, only the 27 antisera that contained K88 antibody inhibited the bacterial and cell-free haemagglutinins of strain WI. Because all the antisera had been prepared from materials that contained both haemagglutinin and K88 antigen, haemagglutination inhibition may not be attributable solely to K88 antibody. To determine whether K88 antigen and haemagglutinin were associated with the same antigenic component, OK antisera prepared against W I and w9 (K88ac-positive) and $w_{3}$ and w5 (K88ab-positive) were absorbed with live cultures of each strain to remove $\mathrm{K}$ antibodies and the changes in h.i. and agglutinin titres were then measured in tests with live cultures.

Unabsorbed sera inhibited haemagglutination by the four strains. The changes in the h.i. and K88 agglutinin titres of absorbed antisera were similar. For example, absorption of w I OK antisera with $\mathrm{w}_{3}$ cultures resulted in loss of agglutinating and h.i. activity against $\mathrm{w}_{3}$ and $\mathrm{w}_{5}$ but not against $\mathrm{wI}_{\mathrm{I}}$ and w9; this can be attributed to absorption of K88a. Absorption of wI OK antisera with w9 cultures resulted in loss of agglutinating and h.i. activity against all strains, and results with the other absorbed antisera supported the conclusion that K88 antigen and haemagglutinin were associated with the same antigenic component. Additional agglutinins in the WI and w9 OK antisera were removed only by absorption with the homologous strain and did not inhibit haemagglutination.

\section{DISCUSSION}

The m.r.e. haemagglutination of guinea-pig red cells by all K88-positive strains of $E$. coli, and its absence in cultures grown at $18{ }^{\circ} \mathrm{C}$ and in K88-negative mutants of strain WI, suggested that the m.r.e. haemagglutinin detected in the microhaemagglutination test was the K88 antigen. This conclusion was supported by haemagglutination inhibition tests which demonstrated that $\mathrm{K} 88$ antigen accounted for the haemagglutinating activity of strain WI, and that K88 and haemagglutinin were antigenically similar in three other cultures. However, it is possible that inhibition of the haemagglutinin is due to precipitation and inactivation of the K88 antigen, and not to the binding of antibody to the active site of the haemagglutinin. Fractionation studies indicated that K 88 and haemagglutinin eluted together, but the occasional elution of two peaks, A and B, containing K88 antigen and haemagglutinin from DEAE cellulose requires explanation. Polyacrylamide gel electrophoresis studies indicated that partial degradation of the antigen rather than two species of K88 accounts for this result, so that peak B probably consisted of degraded K88 antigen. Degradation may also account for the different ratios of $\mathrm{K} 88$ to haemagglutinin in peak A compared with peak B, since the movement of K88 antigen through agar is known to be retarded by its filamentous nature (Ørskov, Ørskov, Jann \& Jann, I97I).

The haemagglutinins produced by K88-positive cultures were detected only in the microhaemagglutination test and the different behaviour of K88-positive cultures in the microhaemagglutination and tile haemagglutination tests may be attributed to the low affinity of the haemagglutinin for the surface of the erythrocytes; this view is supported by the temperature dependence and thermal elution of the haemagglutinins, both of which are probably caused by thermal agitation. The greater shearing forces generated in the tile test may be sufficient to disrupt the relatively weak bonds between the red cell and the m.r.e. haemagglutinin. In contrast, three K88-negative cultures caused m.r.e. haemagglutination of 
guinea-pig red cells only in the tile technique, suggesting that these bacteria require greater and more frequent collisions with the red cell before adhesion occurs.

K88-positive cultures agglutinated all the samples of guinea-pig red cells examined but did not agglutinate red cells from all the animals of any other species; additional m.r.e. haemagglutinins were not detected with the tile test and it seems that individual differences may occur in the affinity and availability of the red cell receptor for the K88 haemagglutinin. Our observations that red cells from a single animal were not agglutinated by all the K88positive strains examined may explain the results of Punyashthiti \& Finkelstein (I97I) who found that only one of six K88-positive cultures agglutinated fowl red cells. Similar variations in the reactions of red cells from different species have been observed with other m.s. and m.r.e. haemagglutinins (Duguid, 1964).

The m.r.e. haemagglutination of guinea-pig erythrocytes distinguished K88-positive strains of $E$. coli from K88-negative enteropathogenic strains and other strains of porcine origin. The absence of haemagglutinating activity in K88-negative enteropathogenic strains is surprising because attachment of strains of the same serotypes to the intestinal mucosa of pigs has been described in vivo (Smith \& Halls, 1968; Drees \& Waxler, 1970). Recently, we have confirmed that these strains do not haemagglutinate red cells from other species, and since they do not attach to tissue from the small intestine of piglets in vitro (Jones \& Rutter, I972) it appears that these K88-negative pathogens do not produce adhesive sub stances when grown on laboratory media, but may do so in vivo.

Jones \& Rutter (1972) showed that only K88-positive $E$. coli attached to piglet intestinal tissue; adhesion was inhibited by $\mathrm{K} 88$ antiserum and was absent from cultures grown at $18{ }^{\circ} \mathrm{C}$ and from K88-negative mutants of strain WI. The similarity between the m.r.e. haemagglutinin and the adhesin of K88-positive E. coli suggests that the mechanism of haemagglutination and attachment to the mucosa of the piglet intestine may be similar. Possibly the K88 antigen reacts with a glycoprotein receptor in the intestinal mucus (Jones, I972) similar to that present on the surface of guinea-pig erythrocytes.

Adhesive and haemagglutinating properties have been recognized in many species of Enterobacteriaceae (Duguid, Smith, Dempster \& Edmunds, 1955; Duguid \& Gillies, 1957, 1958; Duguid, 1959; Duguid, Anderson \& Campbell, I966), and the adhesive mechanisms that enable $E$. coli strains pathogenic for calves (Smith \& Orcutt, 1925) and infants (Drucker, Yeivin \& Sacks, 1967) to attach to the mucosa of gut, and the adhesive properties described in Streptococcus pyogenes (Ellen \& Gibbons, 1972) and Vibrio cholerae (Freter, 1969), may also cause agglutination of suitable erythrocytes. Recently, m.r.e. haemagglutination has been detected in cultures of $E$. coli that are pathogenic for calves (M. R. Burrows, personal communication) and in an enteropathogenic strain of K88-negative E. coli (G. W. Jones and G. T. H. Brown, unpublished results) that is known to attach to the gut wall of piglets (Bertschinger, Moon \& Whipp, 1972). Thus, in vitro techniques that demonstrate bacterial attachment may be of value in the elucidation of an important step in the pathogenesis of some bacterial diseases. 


\section{REFERENCES}

Arbuckle, J. B. R. (1970). The location of Escherichia coli in the pig intestine. Journal of Medical Microbiology 3, 333-340.

Bertschinger, H. U., Moon, H. W. \& Whipp, S. C. (1972). Association of Escherichia coli with the small intestinal epithelium. I. Comparison of enteropathogenic and non-enteropathogenic porcine strains in pigs. Infection and Immunity 5, 595-605.

BrakKe, M. K. (I967). Density-gradient centrifugation. In Methods in Virology, vol. 2, pp. 93-I I8. Edited by K. Maramorosch and $\mathrm{H}$. Koprowski. New York and London: Academic Press.

CowAN, S. T. \& STEEL, K. J. (1965). Manual for the Identification of Medical Bacteria, Ist edn. Cambridge: Cambridge University Press.

Cruickshank, R. (1965). Medical Microbiology, 1 ith edn. Edinburgh and London: Livingstone.

DREEs, D. T. \& WAXLER, G. L. (I970). Enteric colibacillosis in gnotobiotic swine: a flourescent microscopic study. American Journal of Veterinary Research 31, I $147-1,157$.

Drucker, M. N., Yeivin, R. \& Sacks, T. G. (I967). Pathogenesis of Escherichia coli enteritis in the ligated rabbit gut. Israel Journal of Medical Science 3, 445-452.

DuguID, J. P. (1959). Fimbriae and adhesive properties in Klebsiellastrains. Journal of General Microbiology $21,27 \mathrm{I}-286$.

Duguid, J. P. (1964). The functional anatomy of Escherichia coli with special reference to enteropathogenic E. coli. Revista latinoamericana de microbiologia $7, \mathrm{I}-\mathrm{I} 6$.

Duguid, J. P. (I968). The function of bacterial fimbriae. Archivum immunologiae et therapiae experimentalis I6, I $73-188$.

Duguid, J. P., Anderson, E. S. \& CAmpbell, I. (I966). Fimbrial and adhesive properties in Salmonellae. Journal of Pathology and Bacteriology 92, $107-138$.

Duguid, J. P. \& Gillies, R. R. (I957). Fimbriae and adhesive properties in dysentery bacilli. Journal of Pathology and Bacteriology 74, 397-4II.

Duguid, J. P. \& Gillies, R. R. (I958). Fimbriae and haemagglutinating activity in Salmonella, Klebsiella, Proteus and Chromobacterium. Journal of Pathology and Bacteriology 75, 519-520.

Duguid, J. P., Smith, I. W., Dempster, G. \& Edmunds, P. N. (I955). Non-flagellar filamentous appendages ('fimbriae') and haemagglutinating activity in Bacterium coli. Journal of Pathology and Bacteriology 70, 335-348.

EDWARDS, P. R. \& EwING, W. H. (1962). Identification of Enterobacteriaceae, 2nd edn, pp. 6I-9I. Minneapolis: Burgess Publishing.

Ellen, R. P. \& Gibbons, R. J. (I972). M protein-associated adherence of Streptococcus pyogenes to epithelial surfaces: prerequisite for virulence. Infection and Immunity 5, 826-830.

Freter, R. (1969). Studies of the mechanism of action of intestinal antibody in experimental cholera. Texas Reports on Biology and Medicine 27, 299-316.

JONES, G. W. (1972). The adhesive properties of $K 88$ antigen of strains of Escherichia coli pathogenic to neonatal pigs. Ph.D. thesis, University of Reading.

JONES, G. W. \& RutTER, J. M. (1972). Role of the K88 antigen in the pathogenesis of neonatal diarrhoea caused by Escherichia coli in piglets. Infection and Immunity 6, 91 8-927.

Lowry, O. H., Rosebrough, N. J., FarR, A. L. \& Randall, R. J. (195I). Protein measurement with the Folin phenol reagent. Journal of Biological Chemistry 193, 265-275.

Mancini, A., Carbonara, A. O. \& Heremans, J. F. (1965). Immunochemical quantitation of antigens by single radial immunodiffusion. Immunochemistry 2, 235-254.

Ørskov, I. \& ØRSKOv, F. (1966). Episome-carried surface antigen K88 of Escherichia coli. I. Transmission of the determinants of the K88 antigen and influence on the transfer of chromosomal markers. Journal of Bacteriology 91, 69-75.

ØRSKov, F., ØRSKov, I., JANN, B. \& JANN, K. (I97I). Immunoelectrophoretic patterns of extracts from all Escherichia coli $\mathrm{O}$ and $\mathrm{K}$ antigen test strains correlated with pathogenicity. Acta pathologica et microbiologica scandinavica 79, I42-152.

Ørskov, I., Ørskov, F., Sojka, W. J. \& Leach, J. N. (I96I). Simultaneous occurrence of E. coli B and $\mathrm{L}$ antigens in strains from diseased swine. Influence of cultivation temperature on two new E. coli $\mathrm{K}$ antigens $\mathrm{K} 87$ and K88. Acta pathologica et microbiologica scandinavica $\mathbf{5 3}, 404-422$.

Ørskov, I., Ørskov, F., SojkA, W. J. \& Wittig, W. (1964). K antigens K88ab (L) and K88ac (L) in E. coli. A new $\mathrm{O}$ antigen: OI47 and a new K antigen: K89 (B). Acta pathologica et microbiologica scandinavica 62, 439-447. 
Powell, C. J. \& Finkelstein, R. A. (I966). Virulence of Escherichia coli strains for chick embryos. Journal of Bacteriology 9I, I4IO--I4I7.

Punyashthiti, K. \& Finkelstein, R. A. (I97I). Enteropathogenicity of Escherichia coli. I. Evaluation of mouse intestinal loops. Infection and Immunity 4, 473-478.

SCHERER, R. K. (1966). Colonial morphology of Escherichia coli on Tergitol-7 medium. Applied Microbiology $14, \mathrm{I} 52-\mathrm{I} 55$.

Smith, H. W. \& Halls, S. (1968). The production of oedema disease and diarrhoea in weaned pigs by the oral administration of Escherichia coli. Factors that influence the course of the experimental disease. Journal of Medical Microbiology r, 45-59.

SMith, H. Williams \& Linggood, M. A. (I970). Transfer factors in Escherichia coli with particular regard to their incidence in enteropathogenic strains. Journal of General Microbiology 62, 287-299.

Smith, H. Williams \& Linggood, M. A. (I97I). Observations on the pathogenic properties of the K88, Hly and Ent plasmids of Escherichia coli with particular reference to porcine diarrhoea. Journal of Medical Microbiology 4, 467-485.

SMITH, T. \& ORCUTT, M. L. (I925). The bacteriology of the intestinal tract of young calves with special reference to the early diarrhoea ('Scours'). Journal of Experimental Medicine 4I, 89-106.

Sojka, W. J. (1965). Escherichia coli in Animals. ist edn. Farnham Royal: Commonwealth Agricultural Bureaux.

SoJKA, W. J. (1971). Enteric diseases in new-born piglets, calves and lambs due to Escherichia coli infection. Veterinary Bulletin 4I, 509-522.

Stirm, S., ØRSkov, F., Ørskov, I. \& BIRCH-ANDERSEN, A. (1967a). Episome-carried surface antigen K88 of Escherichia coli. III. Morphology. Journal of Bacteriology 93, 740-748.

StIRM, S., ØRskov, F., Ørskov, I. \& MANSA, B. (1967 b). Episome-carried surface antigen K88 of Escherichia coli II. Isolation and chemical analysis. Journal of Bacteriology 93, 73I-739.

Virella, G. \& Parkhouse, R. M. E. (197I). Detection of monomeric IgM by acrylamide disc gel electrophoresis followed by agar gel immunodiffusion. Clinica chimica acta 32, 427-43I. 